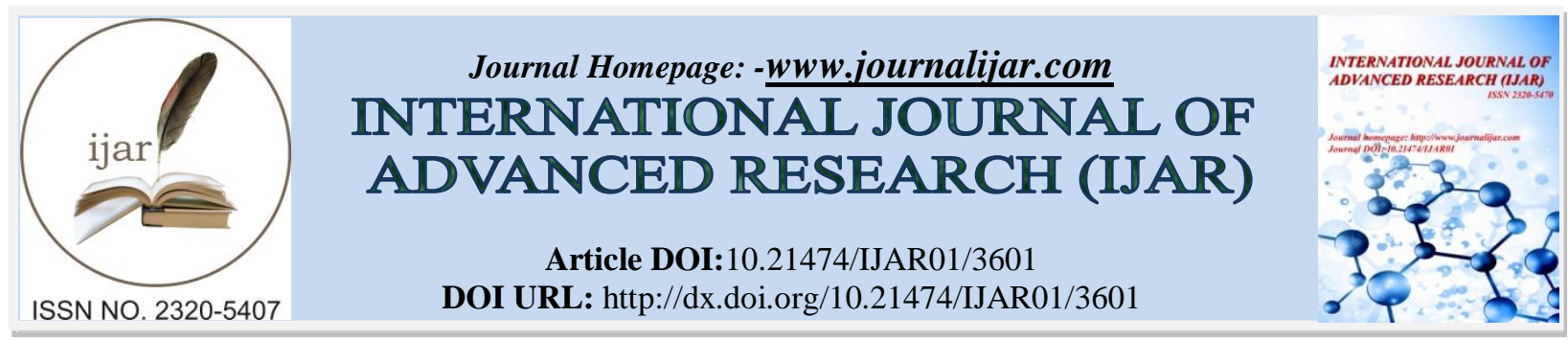

RESEARCH ARTICLE

\title{
INTER-DISTRICT DISPARITIES IN INDUSTRIAL GROWTH OF ASSAM.
}

Sangeeta Baruah ${ }^{1}$ and M. Borah ${ }^{2}$.

1. Research Scholar, Department of Mathematical Sciences, Tezpur University, Tezpur.

2. Professor, Department of Mathematical Sciences, Tezpur University, Tezpur.

\section{Manuscript Info}

Manuscript History

Received: 06 January 2017

Final Accepted: 03 February 2017

Published: March 2017

Key words:-

Composite index, Development indicators, Model districts, Potential targets.

\begin{abstract}
The level of industrial development across different districts of the state has been worked out with the help of composite indices. The composite indicators are obtained with the help of two different methods. The district-wise data in respect of forty three indicators are used for twenty three districts of the State. The data on most of the indicators are for the year 2013-2014. Ranks of the districts in the level of industrial development are obtained from both the methods, which are later compared. It is observed that there is no significant difference between the ranks obtained from the two methods used. The study has brought out the huge disparities that exist among the districts which have accentuated over a period of time.The district Kamrup is ranked first and the district Hailakandi is ranked last. For bringing out uniform regional development, potential targets have been estimated for low developed districts. These districts require improvements of various dimensions in some of the indicators for enhancing the level of overall socio-economic development.
\end{abstract}

Copy Right, IJAR, 2017,. All rights reserved.

\section{Introduction:-}

The problem of inter-district disparity in the levels of development is not of recent origin and is almost universal. Its extent may differ in different economics but its existence can hardly be challenged. Economic development is a concern of all societies as well as the nations. During the course of economic development, the determinants of developmental process shape up in the form of agrarian transformation towards non-agricultural sectors. Also, at some stage of economic development, increasing urbanization, improved quality of infrastructure, increased standard of living of human beings and the improved quality of overall governance take place. However, in this process of development, some regions of the economy grow faster whereas others tend to lag behind.

Assam had a great legacy of modern industrial development. Along with tea, oil refineries and coal mines were developed post-independence. A number of major industries based on the rich mineral and forest resources were set up under the central public sector. Fertilizer industry, Namrup; Cement factory, Bokajan and Paper mill at Jagiroad etc. were also set up. Assam produces three unique varieties of silk; the golden muga, the white pat and warm eri. Sericulture is one of the biggest contributors of state income. It is practiced in more than 9373 villages and provides employment to 2.4 lakh families. Eri contributes Rs 31.5 crores where as muga contributes Rs 40 crores and pat silk contributes Rs 120 crores out of total Rs 190 crores generated annually through the silk industry in Assam. The Assam Handloom Industry is known for its tradition of making handloom and handicraft products. At present, 11570 villages of the state with 1319754 weavers are covered by the directorate of Handloom and Textiles for its

Corresponding Author:- Sangeeta Baruah.

Address:-Research Scholar, Department of Mathematical Sciences, Tezpur University, Tezpur. 
handloom activities. The Small Scale Industrial (SSI) Sector is a vital constituent of the total industrial sector. Electricity, good roads and transport system are the key indicators of development in a region. A better transport system increase income, employment opportunities, tourism, and industrial development in many ways. But there are differences in all the districts of the State as far as industrial growth is concerned. All the districts of the State are not equally developed. So, we have made an attempt to throw light on the developmental disparities in industrial growth for twenty three districts of the State. Development is a process which improves the quality of life. Its impact cannot be fully captured by a single indicator. Hence there is need for building up of a composite index of development, combined in an optimum manner. A deep analysis using the district level data on socio-economic indicators was made by Narain et. al. for the States Orissa [1992-1993], Andhra Pradesh [1994], Kerala [1994] Uttar Pradesh, [1995] Maharashtra [1996], Karnataka [1997], Tamil Nadu [2000], Madhya Pradesh [2002]. Similar study had been made by Borah and Nath for Assam [2004, 2010]. In all, the study for evaluating the level of socioeconomic development was conducted in two hundred twenty eight districts belonging to the states of Andhra Pradesh, Karnataka, Kerala, Madhya Pradesh, Maharashtra, Orissa, Tamil Nadu and Uttar Pradesh and it was found that 73 districts were low developed which require special attention for undertaking future developmental programmes.

\section{Methods of Analysis:-}

Development is a multi-dimensional continuous process. For this study, the districts have been taken as the unit of analysis. Twenty three districts of the state of Assam are included in the study. Two methods have been separately used to rank the districts of the state, viz. Narain et. al. method and Michela et. al. method.

\section{Narain Et. Al. Method:-}

Let a set of $\mathrm{n}$ points represent districts $1,2, \ldots, \mathrm{n}$ for a group of indicators $1,2, \ldots, \mathrm{k}$, which can be represented by a matrix $\left(\mathrm{X}_{\mathrm{ij}}\right) ; \mathrm{i}=1,2, \ldots, \mathrm{n}$ and $\mathrm{j}=1,2, \ldots, \mathrm{k}$. As the developmental indicators included in the analysis are in different units of measurement and since our objective is to arrive at a single composite index relating to the dimension in question. There is a need for standardized as shown below [Narain et. al., 1991]:

$$
\begin{aligned}
& Z_{i j}=\frac{X_{i j}-\bar{X}_{j}}{S_{j}}, \\
& S_{j}^{2}=\frac{\sum_{i=1}^{n}\left(X_{i j}-\bar{X}_{j}\right)^{2}}{n}
\end{aligned}
$$

and

$$
\overline{\mathrm{X}}_{\mathrm{J}}=\sum_{\substack{\mathrm{i}=1 \\(\mathrm{i}=1,2, \ldots, \mathrm{n}), \quad(\mathrm{j}=1,2, \ldots, \mathrm{k})}}^{\mathrm{X}_{\mathrm{ij}}}
$$

Let $\left\lfloor Z_{\mathrm{ij}}\right\rfloor$ denote the matrix of standardized indicators. The best district for each indicator (with maximum/minimum standardized value depending upon the direction of the indicator) is identified and from this the deviations of the value for each district has been taken for all indicators in the following manner:

$$
C_{i}=\left(\sum_{j=1}^{k}\left(Z_{i j}-Z_{0 j}\right)^{2}\right)^{1 / 2},
$$

where $Z_{0 \mathrm{j}}$ the standardized value of the jth indicator of the best district and $\mathrm{C}_{\mathrm{i}}$ denotes the pattern of development of $i^{\text {th }}$ district.

The pattern of development is useful in identifying the districts which serve as 'models' and it also helps in fixing the potential target of each indicator for a given district. In this study, the composite index of development is obtained through the following formula: 


$$
\begin{gathered}
\mathrm{D}_{\mathrm{i}}=\frac{\mathrm{C}_{\mathrm{i}}}{\mathrm{C}}, \\
\mathrm{C}=\overline{\mathrm{C}}+2 \mathrm{~S} \\
\text { where } \overline{\mathrm{C}}=\sum_{\mathrm{i}=1}^{\mathrm{n}} \frac{\mathrm{C}_{\mathrm{i}}}{\mathrm{n}} \\
\qquad S=\left(\sum_{i=1}^{n} \frac{\left(C_{i}-\bar{C}\right)^{2}}{n}\right)^{1 / 2} .
\end{gathered}
$$

\section{Michela Et. Al Method:-}

Theoretical frame work and methodology is followed from [14]. The aggregated values give the composite index of development to rank the districts. A theoretical framework should be developed to provide the basis for the selection and combination of single indicators into a meaningful composite index. The indicators should be selected on the basis of their analytical soundness, measurability, country coverage, relevance to the phenomenon being measured and relationship to each other. The use of proxy variables should be considered when data are scarce.

A multivariate analysis should be done to investigate the overall structure of the indicators, assess the suitability of the data set and explain the methodological choices. The next step is normalization in which the indicators should be normalized to render them comparable.

$$
Z_{i j}=\frac{X_{i j}-\bar{X}_{j}}{S_{j}}
$$

A correlation study is done to find the redundancy in the indicators, and the correlation co-efficient is given by:

$$
\mathrm{r}_{\mathrm{zi}, \mathrm{zj}}=\frac{\sum\left(\mathrm{z}_{\mathrm{i}}-\overline{\mathrm{z}_{\mathrm{i}}}\right)\left(\mathrm{z}_{\mathrm{j}}-\overline{\mathrm{z}_{\mathrm{j}}}\right)}{\sqrt{\sum\left(\mathrm{z}_{\mathrm{i}}-\overline{\mathrm{z}_{\mathrm{i}}}\right)^{2}} \sqrt{\sum\left(\mathrm{z}_{\mathrm{j}}-\overline{\mathrm{z}_{\mathrm{j}}}\right)^{2}}}
$$

We discard the indicators having high correlation co-efficient with other indicators and as such the number of indicators reduces.

Finally weighting and aggregation is done in which the indicators should be aggregated and weighted according to the underlying theoretical framework.

$$
\mathrm{A}_{\mathrm{i}}=\sum_{\mathrm{j}} \mathrm{z}_{\mathrm{ij}}
$$

The aggregated values give the composite index of development to rank the districts.

Relative Share of Area and Population under Different Level of Development:-

A simple ranking of district on the basis of composite indices is sufficient but a suitable classification of districts formed on the basis of mean and standard deviation of the composite indices will provide a more meaningful characterization of various stages of development. For relative comparison it appears appropriate to assume the districts having composite index less than or equal to (Mean - SD) as highly developed districts. And the districts having composite index greater than or equal to (Mean $+\mathrm{SD}$ ) be low developed districts. Similarly districts with composite index lying between (Mean and Mean - SD) are classified as middle level developed and district with composite index lying between (Mean and Mean + SD) are classified as developing districts.

\section{Fixation of Potential Targets:-}

Using the standardized variates $\left[\mathrm{Z}_{\mathrm{ij}}\right\rfloor$, the economic distance between different districts may be obtained as follows: 


$$
\begin{aligned}
& D_{i p}=\left(\sum_{j=1}^{k}\left(Z_{i j}-Z_{p j}\right)^{2}\right)^{1 / 2}, \\
& (\mathrm{i}=1,2, \ldots, \mathrm{n} \text { and } \mathrm{p}=1,2, \ldots \mathrm{n}) .
\end{aligned}
$$

Here

$$
\mathrm{D}_{\mathrm{ii}}=0 \text { and } \mathrm{D}_{\mathrm{ip}}=\mathrm{D}_{\mathrm{pi}} \text {. }
$$

The distance matrix will take the form:

$$
\left[\begin{array}{cccc}
0 & d_{12} & d_{13} \ldots & d_{1 n} \\
d_{21} & 0 & d_{23} \ldots & d_{2 n} \\
& & \cdot & \\
d_{n 1} & d_{n 2} & d_{n 3} \ldots & 0
\end{array}\right] .
$$

The minimum distance for each row, $\left(d_{i}, i=1,2, \ldots, n\right)$ will be obtained from the distance matrix for computation of upper and lower limits (C.D.) as indicated below:

$$
\text { C. D. }=\overline{\mathrm{d}} \pm 2 \sigma_{\mathrm{d}},
$$

where

$$
\begin{aligned}
& \bar{d}=\sum_{i=1}^{n} \frac{d_{i}}{n}, \\
& \sigma_{d}=\left(\sum_{i=1}^{n} \frac{\left(d_{i}-\bar{d}\right)^{2}}{n}\right)^{1 / 2} .
\end{aligned}
$$

and

The distance matrix can also be used for fixing targets for different districts on each indicator, which would be in the direction of reducing the disparities. The districts should be identified which are homogeneous with a close proximity to each other with the district under consideration, in terms of considered indicators. For setting out the targets, the model districts are to be identified on the basis of composite index and individual distance with districts. The best values among the model districts will be taken as potential target for a particular district for a given indicator. This procedure will be repeated for a given district for all indicators considered. This would give the extent of improvement required in different indicators for balanced development in the district. It also provides avenues to bring about uniform regional development in the state. Such information helps the planners and administrators to readjust the resources to reduce inequalities in level of development among different districts of the state.

The study utilizes data on most of the industry sector indicators for the year 2013-2014. A total of forty three development indicators have been included in the study.

\section{Developmental Indicators:-}

Each district faces situational factors of development unique to it as well as common administrative and financial problems. The composite indices of development for different districts have been obtained by using the data on the following indicators. The different indicators are classified into the following categories [16].

$[\mathrm{X}]$ Handloom

$\mathrm{x}_{1}$ : No. Of HTC

$\mathrm{x}_{2}$ : No. Of trainees in HTC

$\mathrm{x}_{3}$ : No. Of WESU

$\mathrm{x}_{4}$ : Production of WESU

$\mathrm{x}_{5}:$ No. of HDC

$\mathrm{x}_{6}$ : Production of HDC

$\mathrm{x}_{7}$ : No. of weavers engaged in HDC, part time

$\mathrm{x}_{8}$ : No. of weavers engaged in HDC, full time 


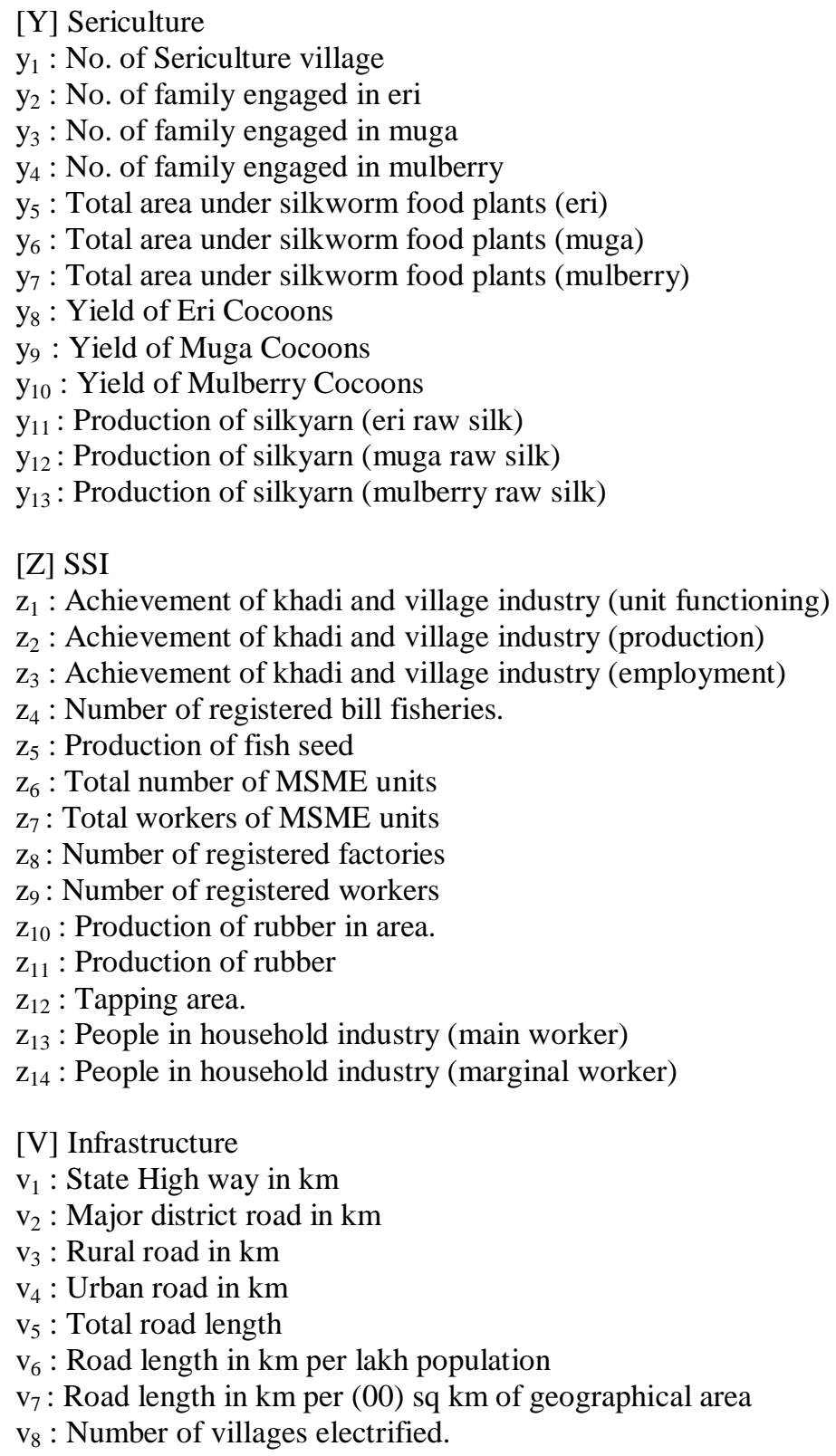

\section{Comparison of Ranks:-}

We have used Spearman rank correlation co-efficient to test if there is any significant difference in the ranks obtained by the two methods. The rank correlation co-efficient is given by Ronald et. al.(1985)

$$
\mathrm{r}_{\mathrm{s}}=1-\frac{6 \sum_{\mathrm{i}=1}^{\mathrm{n}} \mathrm{d}_{\mathrm{i}}{ }^{2}}{\mathrm{n}\left(\mathrm{n}^{2}-1\right)}
$$

where $d_{i}$ is the difference between the ranks assigned by the two methods and $n$ is the number of pairs of data [15]. 


\section{Results and Discussions:-}

The Level of Development:-

The districts have been ranked on the basis of development indices. Table-1 presents the composite indices of development along with the ranks of different districts. It may be seen from the above table that out of 23 districts of the State, the district Kamrup is ranked first whereas the district Hailakandi is ranked last in the overall industrial growth.

Table 1:- Ranks of all the districts of Assam obtained from the two methods.

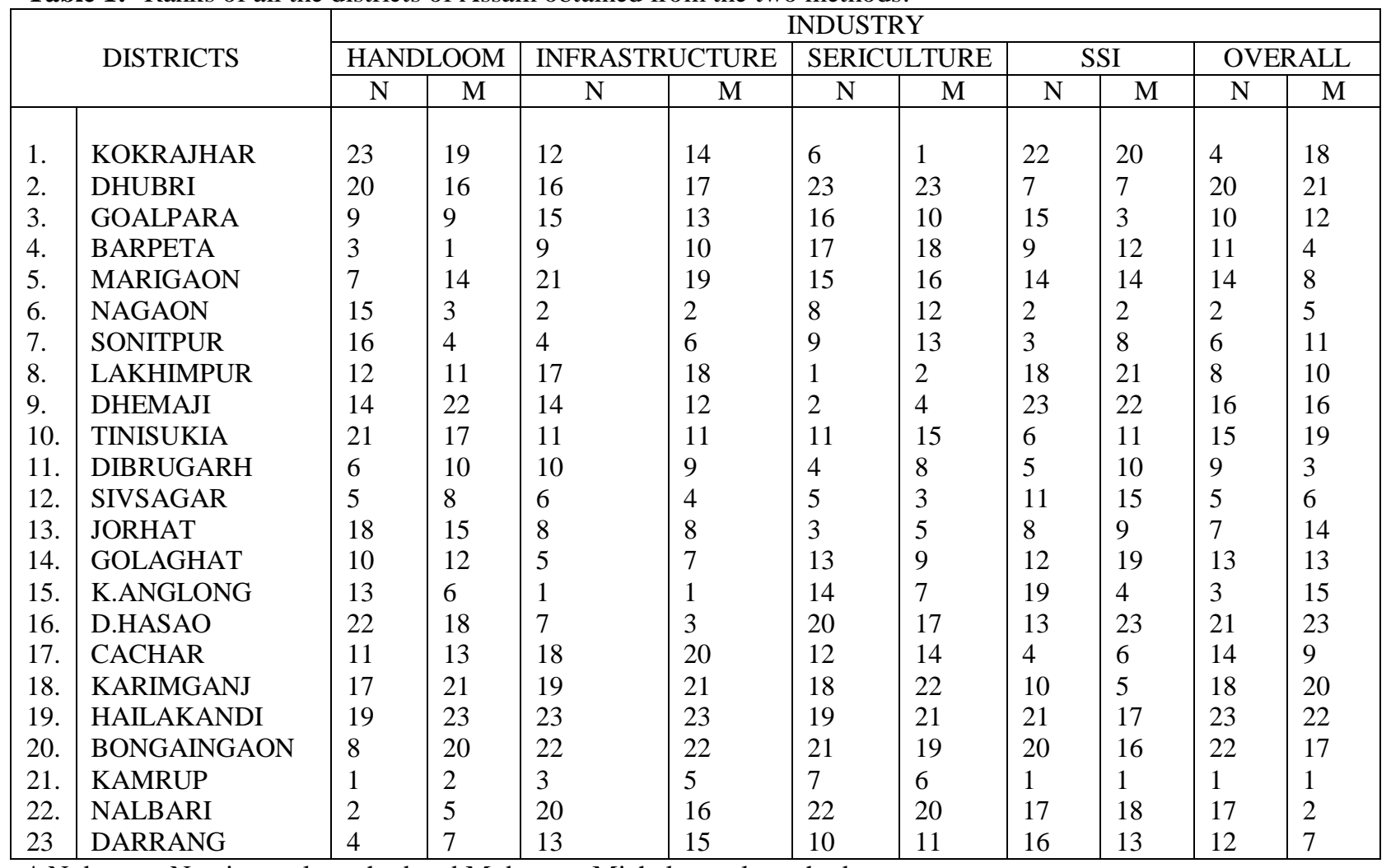

* $\mathrm{N}$ denotes Narain et. al. method and M denotes Michela et. al. method.

It is seen that, for most of the districts, ranks calculated by the two methods are almost same whereas for a few other districts, ranks calculated by the two methods are different.

We have tested the hypothesis that the correlation between the ranks obtained by Narain et. al. method and the Michela et. al. method is zero against the alternative hypothesis that it is greater than zero. At both 0.01 and 0.05 level of significance, it is observed that the two methods are correlated and there is no significance difference between the ranks obtained from the two methods.

Area and Population in Different Stages of Development:-

It would be quite interesting and useful to find out the relative share of area and population affected under different levels of development in the State. The area and population covered by the districts falling under different levels of development are presented in Table 2.

Table 2:-Area and Population under Different Levels of Development

\begin{tabular}{|l|l|l|l|}
\hline Level of Development & No. of Districts & Population $(\%)$ & Area $(\%)$ \\
\hline High $(\leq 0.679)$ & 3 & 17.7 & 23.8 \\
Medium $(0.679-0.786)$ & 7 & 32.8 & 27.4 \\
Developing $(0.786-0.892)$ & 10 & 41.7 & 37.7 \\
Low $(\geq 0.892)$ & 3 & 7.8 & 11.1 \\
\hline
\end{tabular}

It is evident from the table that about $23.8 \%$ area consisting of about $17.7 \%$ population of the State fall in the districts which are high developed. About $11.1 \%$ area and $7.8 \%$ population fall in the districts which are low developed in the industrial sector. The low developed districts which have been found in this study are Hailakandi, Bongaingaon and Dima-Hasao. List of model districts for these low developed districts is presented in Table-3. 
Table 3:-Model Districts for Low-developed Districts

\begin{tabular}{|l|l|l|}
\hline S. No. & Low Developed Districts & Model Districts \\
\hline 1. & Hailakandi & Morigaon, Kamrup, Golaghat, Nalbari \\
2. & Bongaingaon & Morigaon, Kamrup, Nagaon, Cachar \\
3. & Dima-Hasao & Kamrup, Karbi-Anglong, Cachar, Nalbari, Nagaon \\
\hline
\end{tabular}

The districts Kamrup, Nagaon andMorigaon are found to be the model districts for most of the low developed districts.

Potential Targets of Indicators for Low Developed Districts:-

It would be useful to examine the extent of improvements required in different indicators of the low developed districts for enhancing the level of development. The best values of the indicators of better developed districts will be taken as potential targets for the low developed districts. The extent of improvement needed in various indicators of the low developed districts is given below:

Table 4:-Estimate of Potential Target and Actual achievement (given under the bracket).

\begin{tabular}{|c|c|c|c|c|c|c|c|}
\hline $\begin{array}{l}\text { Indicator } \\
\mathrm{s}\end{array}$ & Hailakandi & Bongaingaon & Dima-Hasao & $\begin{array}{l}\text { Indicat } \\
\text { ors }\end{array}$ & Hailakandi & Bongaingaon & Dima-Hasao \\
\hline $\mathrm{X}_{1}$ & $238.4(16.9)$ & $\begin{array}{l}1709.5(12.55 \\
)\end{array}$ & $\begin{array}{l}1709.5(14.52 \\
)\end{array}$ & $\mathrm{z}_{2}$ & $3007.1(3369.8)$ & $\begin{array}{l}3007.76(2943.9 \\
5)\end{array}$ & $3007.7(163.3)$ \\
\hline $\mathrm{x}_{2}$ & $2549(1000)$ & $2549(1815)$ & $2549(607)$ & $\mathrm{Z}_{3}$ & 19392(9358) & $24262(5800)$ & $24262(280)$ \\
\hline $\mathrm{X}_{3}$ & $672(90)$ & $672(29)$ & $672(21)$ & $\mathrm{z}_{4}$ & $12(0.2)$ & $10(0.4)$ & $10(0.9)$ \\
\hline $\mathrm{x}_{4}$ & $230(99)$ & $326(16)$ & $326(199)$ & $\mathrm{Z}_{5}$ & $1(0.45)$ & $0.9(0.75)$ & $.69(.12)$ \\
\hline $\mathrm{X}_{5}$ & $5(1)$ & $8(3)$ & $8(.4)$ & $\mathrm{z}_{6}$ & $620.02(326.25)$ & $620.02(321.62)$ & $620.02(43.25)$ \\
\hline $\mathrm{x}_{6}$ & $100(15)$ & $122(27)$ & $122(40)$ & $\mathrm{z}_{7}$ & $185(25.95)$ & $90.14(33.15)$ & $90.14(90.23)^{*}$ \\
\hline $\mathrm{x}_{7}$ & $7(2)$ & $7(2)$ & $7(5)$ & $\mathrm{Z}_{8}$ & $234.2(71.75)$ & $213.22(109.88)$ & $213.2(878.57)$ \\
\hline $\mathrm{x}_{8}$ & $11(5)$ & $17(5)$ & $17(11)$ & $\mathrm{z}_{9}$ & $95.59(35.6)$ & $92.86(46.66)$ & $95.59(38.38)$ \\
\hline $\mathrm{y}_{1}$ & 1807(98) & 1807(59) & $1807(46)$ & $\mathrm{z}_{10}$ & $2916(351)$ & $2916(712)$ & 2916(1237) \\
\hline $\mathrm{y}_{2}$ & $10829(2950)$ & 10829(2996) & $10829(5045)$ & $\mathrm{z}_{11}$ & $160(17)$ & $297(41)$ & $297(380)^{*}$ \\
\hline $\mathrm{y}_{3}$ & $1850(98)$ & $1850(59)$ & $1850(46)$ & $\mathrm{Z}_{12}$ & $89.4(49.14)$ & $675.25(462.3)$ & $675.25(38.24)$ \\
\hline $\mathrm{y}_{4}$ & $84(35)$ & $134(47)$ & 134(1) & $\mathrm{Z}_{13}$ & $489.6(180)$ & $584.9(198.6)$ & $584.9(358.8)$ \\
\hline $\mathrm{y}_{5}$ & 1343(39) & $1343(64)$ & $1343(26)$ & $\mathrm{Z}_{14}$ & $868(243)$ & $868(259)$ & $868(178)$ \\
\hline $\mathrm{y}_{6}$ & $42770(2957)$ & $42770(5331)$ & $42770(617)$ & $\mathrm{v}_{1}$ & $350(205)$ & $375(265)$ & $375(285)$ \\
\hline $\mathrm{y}_{7}$ & 1304(306) & 1327(844) & 1304(496) & $\mathrm{v}_{2}$ & $183(47)$ & 183(36) & $183(2)$ \\
\hline $\mathrm{y}_{8}$ & $695(357)$ & $675(903)^{*}$ & 1327(198) & $\mathrm{v}_{3}$ & $3235(473)$ & $3235(805)$ & $3235(1876)$ \\
\hline $\mathrm{y}_{9}$ & $72430(10570)$ & $724.3(14929)$ & $72430(390)$ & $\mathrm{v}_{4}$ & $1681(263)$ & 1681(222) & $1681(16)$ \\
\hline $\mathrm{y}_{10}$ & $551(245)$ & $1185(156)$ & $1185(145)$ & $\mathrm{v}_{5}$ & $33(6)$ & $88(36)$ & $88(60)$ \\
\hline $\mathrm{y}_{11}$ & $\begin{array}{l}106803(1200 \\
0)\end{array}$ & $\begin{array}{l}93020(38543 \\
\text { ) }\end{array}$ & $\begin{array}{l}106803(1394 \\
5)\end{array}$ & $\mathrm{v}_{6}$ & $600(10)$ & $500(20)$ & $500(45)$ \\
\hline $\mathrm{y}_{12}$ & $39654(4049)$ & $39654(4729)$ & $39654(742)$ & $\mathrm{v}_{7}$ & $9(4.05)$ & $8.1(6.75)$ & $8.1(1.04)$ \\
\hline $\mathrm{y}_{13}$ & $29452(3264)$ & $29452(4756)$ & $29452(750)$ & $\mathrm{v}_{8}$ & $240.5(33.74)$ & $117.18(43.36)$ & $117(117.68)^{*}$ \\
\hline $\mathrm{z}_{1}$ & $\begin{array}{l}2150.8(1300 . \\
8)\end{array}$ & $575775(900)$ & $\begin{array}{l}575775(1400 \\
)\end{array}$ & & & & \\
\hline
\end{tabular}

*Indicates actual achievement that already better than the potential target.

It is found in the industrial growth sector, that the districts of Kamrup, Nalbari, Dibrugarh and Sibsagar are high developed districts. The districts of Hailakandi, Dhubri and Dima-Hasao are low developed districts. The remaining are middle developed and developing districts.

\section{Conclusion:-}

The broad conclusions emerging from the study are as follow:

Two ranking methods, viz. Narain et. al. and Michela et. al. are used to rank the districts of Assam on the basis of industrial development of the state. It is observed that both the methods gave almost the same ranking. A ranking test is carried out and it is observed that there is no significant difference between the two methods.

With respect to overall development in the industrial progress, the districts of Kamrup, Karbi-Anglong and Nagaon are found to be better developed as compared to the remaining districts of the State. Similarly the districts of Hailakandi, 
Bongaingaon and Dima-Hasao are low developed districts. The level of development in the rest of the districts is of average order but most of these districts are having the tendency to make improvements in the pattern of development.

As compared to the previous study, this study reveals significant changes in the status of the districts Nagaon, Kokrajhar and Karbi-Anglong by improving the ranks and Dibrugarh, Golaghat and Tinisukia by deteriorating their ranks, which may be understood in the light of two different parameters; i) introduction of SSI as one new parameter, ii) improving the status of existing parameters.

Nagaon and Karbi-Anglong gain their rank as SSI index were 2 and 4 which boosted up the overall rank from 6 and 11 to 2 and 3 respectively. Because of consideration of SSI in the new study which was not in the earlier study. Even both the districts show downfall in the indices of handloom in the later study. For the district of Kokrajhar, the better socio-political scenario boosted up the sericulture productivity indices from 20 to 1 and hence overall tabled at rank 4.

For the district of Dibrugarh, deteriorating sericulture sector and average SSI pulled it back and placed it at the rank 9 in lue of 2 in the previous study. Same is the scenario for the district of Golaghat. For Tinsukia district, deteriorating hand loom sector added with poor sericulture and SSI indices pulls back its rank from 10 to 15 .

Despite of all changes in our procedure and timely developmental activities between two studies, Kamrup district holds its original rank.

In order to reduce the disparities, district level studies or setting the objective in the district level may not be a wise idea. So, looking for the potential areas for development in taluka or block level may be of great importance and emphasis on over all developmental indexes will be of good use to reduce the developmental disparities

\section{References:-}

1. Narain, P., Rai, S.C. and Shanti Sarup (1991). Statistical evaluation of development on socio-economic front, J. Ind. Soc. Agril. Statist.,43, 329-345.

2. Narain. P., Rai, S.C. and Shanti Sarup, (1992). Classification of districts based on socio-economic development in Orissa, Yojana, 36, No. 23, 9-12.

3. Narain, P., Rai, S.C. and Shanti Sarup (1993). Evaluation of economic development in Orissa, J. Ind. Soc. Agril. Statist.,45, 249-278.

4. Narain, P., Rai, S.C. and Shanti Sarup (1994). Regional dimensions of socio-economic development in Andhra Pradesh, J. Ind. Soc. Agric. Stat., 46, 156-165.

5. Narain, P., Rai, S.C. and Shanti Sarup (1994). Inter-districts disparities in socio-economic development in Kerala, J.lnd. Soc. Agric. Stat., 46, 362-377.

6. Narain, P., Rai, S.C. and Shanti Sarup (1995). Regional disparities in the levels of development in Uttar Pradesh, J. Ind. Soc. Agric. Stat., 47, 288-304.

7. Narain, P., Rai, S.C. and Shanti Sarup (1996). Dynamics of socio-economic development in Maharashtra, J. Ind. Soc. Agril. Statist.,48, 360-372.

8. Narain, P., Rai, S.C. and Bhatia, V.K., (1997). Regional pattern of socio-economic development in Karnataka, J. Ind. Soc. Agril. Statist.,50, 380-391.

9. Narain, P., Rai, S.C. and Bhatia, V.K., (1999). Inter district variation of development in southern region, J.Ind. Soc. Agril. Statist.,52, 106-120.

10. Narain, P., Sharma, S.D., Rai, S.C. and Bhatia, V.K. (2000). Regional disparities in socio-economic development in Tamil Nadu, J. Ind. Soc. Agril. Statist.,53, 35-46.

11. Narain, P., Sharma, S.D., Rai, S.C. and Bhatia, V.K. (2002). Dimensions of regional disparities in socio-economic development in Madhya Pradesh, J. Ind. Soc. Agril. Statist.,55, 88-107.

12. Nath, A. and Borah, M. (2011). Inter district developmental disparities on Agriculture in Assam, J. Ind. Soc. Agril. Statist, 65, No. 3, 275- 284.

13. Nath, A and Borah, M. (2010). Inter District Development Disparities on Education in Assam, Indian Journal of Social Development, 10, 571-584.

14. Nardo, M., Saisana, M., Saltelli, A. and Tarantola, S. (2008). A Handbook on constructing composite indicators: Methodology and User, OECD publication.

15. Ronald E. Walpole, Raymond H. Myers. (1985). Probability and Statistics for Engineers and Scientists.

16. Statistical Hand Book of Assam, (2013-14). Commissioner of Statistics, Dept. of Statistics, Government of Assam. 